\title{
Aymara Communities in the Lluta River Basin and Precordil- lera of the Arica and Parinacota Region: Agricultural Activities and Economic Projections
}

\author{
Germán Sepúlveda-Chavera $^{1 *}$, Iván Muñoz ${ }^{1}$, Denise Cifuentes² and Patricio Muñoz ${ }^{1,2, *}$ \\ 1 Universidad de Tarapacá, Av. General Velásquez 1775, Arica, Chile; imunoz@uta.cl (I.M.); \\ 2 University of California Davis Chile Life Sciences Innovation Center, Av. Santa María 2670, Tower B, of. \\ 206, Providencia, Santiago, Chile; dcifuentes@ucdavis.edu (D.C.). \\ * Correspondence: gsepulve@uta.cl (G.S.); pmunozt@ucdavis.edu (P.M.); Tel.: +56 582386104
}

\begin{abstract}
The Region of Arica and Parinacota is characterized as an agricultural region located in Atacama Desert at the extreme north of Chile. Its agriculture has allow developing the economy of pre- and post-Hispanic communities, which have been settled since colonial times at different locations in the region. This article is focused on how Aymara communities of Lluta Valley and Precordillera of Arica and Parinacota Region have been included as part of Chilean population, particularly, from social and economic point of view. Furthermore, a characterization of agronomic aspects of the main towns of this zone, and commercialization of agricultural and livestock is included. It must be considered that the evolution of this region would have an important impact in the safeguard on endemic flora and fauna so that it is imperative to protect the genetic heritage of local species and to promote new technologies which allow the production of commercial products from Arica and Parinacota Region.
\end{abstract}

Keywords: Andean agriculture; Indigenous communities; Lluta Valley; Chilean Precordillera

\section{Introduction}

This article has as objective to show how agricultural activities have developed in the valleys of the extreme north of Chile, their importance in the economic development of pre-Hispanic and post-Hispanic communities since colonial times, their inclusion in the republican political process, both in Peru and Chile, and their current projections. The first part presents a historical account of the different cultural periods of the Lluta River basin's original populations and the pre-Hispanic valleys over the last 2,000 years, emphasizing the economic and social aspects that characterized the pre-Hispanic agricultural populations. This analysis is contextualized geographically and territorially, defining the habitat that the populations occupied in these coastal and pre mountain valleys of the Atacama Desert. In the second part, there is a description of the agricultural and livestock activities developed at present in the Lluta Valley, characterized by an eminently agricultural economic trade with some livestock activity traces, mainly focused on an agro-industrial production of national scope. Despite the above, we can see that the upper sectors of the valley have domestic production for family consumption. In the case of the Precordillera valleys, including Codpa Valley, the economy is focused on an agro-livestock sector, where production is for self-consumption, and the surpluses are partially destined to the local and regional market. The third part of the study proposes some ideas regarding the role of agriculture in years to come, which should be supported based on the rescue of some products that marked the history of the regional agricultural economy; improvement of products, such as tomatoes and other livestock commodities such as cheese, introduce them to the regional market and thus strengthening a productive line of the valleys. However, it is essential to point out that it is necessary to train farmers in the technical management of crops, horticultural management, and product marketing to achieve these 
objectives. Parallel to the commercialization of agricultural and livestock products, there must be awareness about the conservation of the genetic heritage of some crops typical of our valleys, so there should be, next to the conservation area, a space that constitutes a botanical garden where the knowledge of plant and species typical of the desert valleys (Figure 1) that make up the region of Arica and Parinacota is studied, preserved and disseminated.

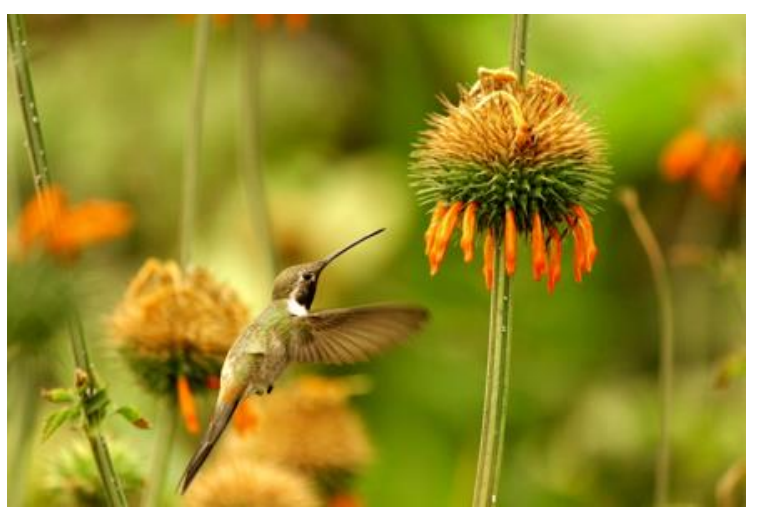

(a)

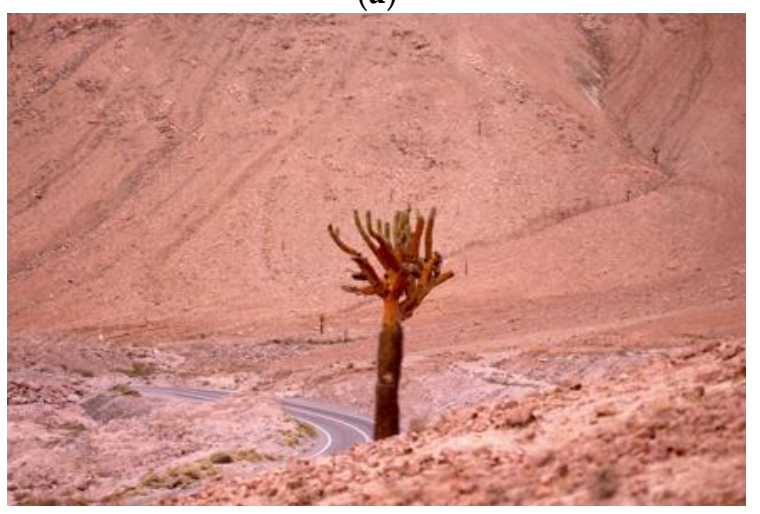

(c)

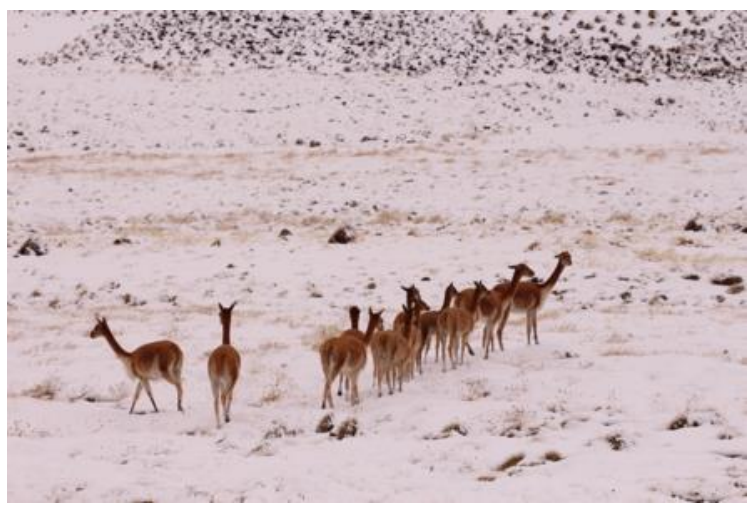

(b)

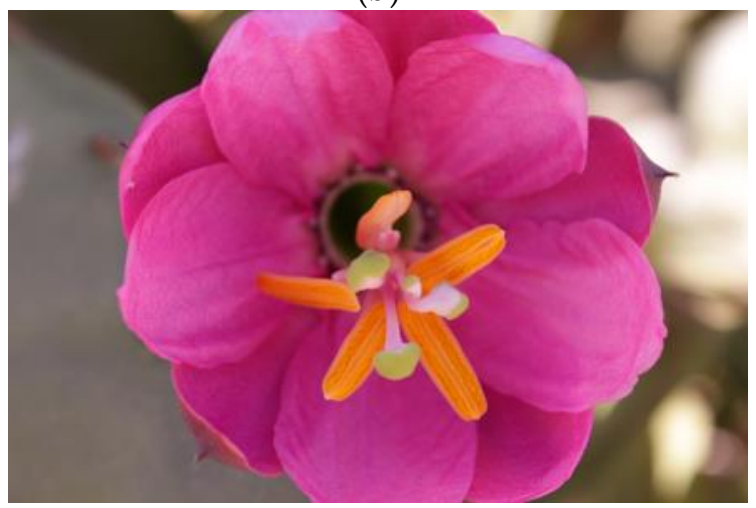

(d)

Figure 1. Some representative flora and fauna of the Region of Arica and Parinacota: (a) Hummingbirds; (b) "Vicuñas"; (c) "Candelabro" cactus; and (d) Tumbo flower.

\section{Geographical and territorial contextualization}

The region of Arica and Parinacota is located in the northern extreme of Chile. It has borders with Peru, Bolivia, and the region of Tarapacá (Chile). From the point of view of the pre-Hispanic past, Arica and Parinacota region was part of the region of the Western valleys of the South-Central Andean Area. The population that originally inhabited these territories corresponded to groups of fishermen and farmers who formed small chiefdoms, establishing multiethnic relationships with groups from other coastal and mountain valleys, some of them linked to altiplanic organizations [1].

The region is part of the Great North or Arid North's natural area, which has extreme aridity as one of its main conditions [2]. However, some environments with the presence of water resources have allowed the development of wildlife and human settlement processes (Figure 2) [3]. The territory that comprises the Arica and Parinacota Region presents differences in the altitudinal gradient, distinguishing, from west to east, four ecological floors in a longitudinal way [4]. According to the description of this author, the ecological floors are The Coast, which is characterized by infrequent coastal plains and abrupt cliffs, with fresh watercourses of summer regime and some river mouths; The desert Pampas, which has areas of extreme aridity, from the 500 meters of altitude, which are cut by 
hydrographic basins, significant from the point of view of biodiversity. Of the hydrographic basins present in the Region of Arica and Parinacota, the only one with an exorheic regime and flows into the sea throughout the year is the Lluta River. The Precordillera, which corresponds to the Andes Mountains western slope, between 2,500 and 3,700 meters above sea level, presents an irregular relief of mountain ranges divided by ravines with permanent watercourses due to summer rains and snow melting during the winter. The Altiplano (highlands), also called Puna, corresponds to an extensive plateau of soft reliefs at an average height of 4,000 meters above sea level, whose physiognomy is altered by volcanic elevations that exceed 5,000 and 6,000 meters above sea level. It also has constant sources of water resources by the presence of glaciers and summer rains. The strong thermal oscillation is one of its distinctive characteristics due to its altitude. By virtue of the altitudinal differences, this vertical zoning of the territory promotes large biodiversity in the region, causing specific adaptive systems for the different ecosystems, both from the point of view of natural resources and from the anthropic perspective $[5,6]$.

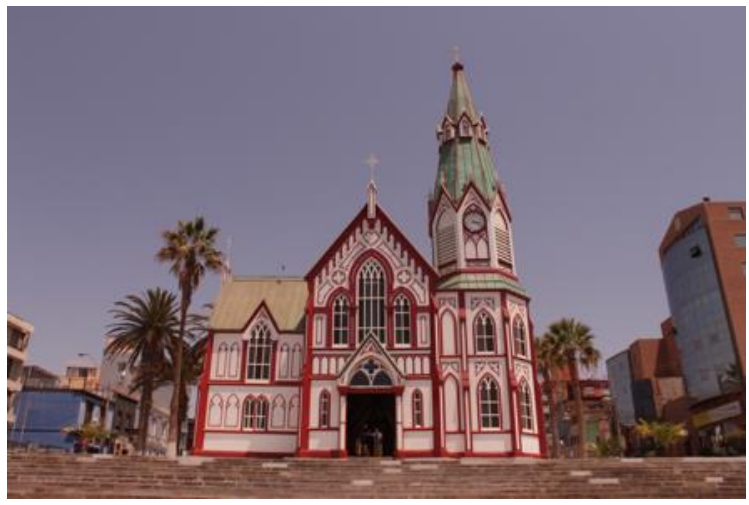

(a)

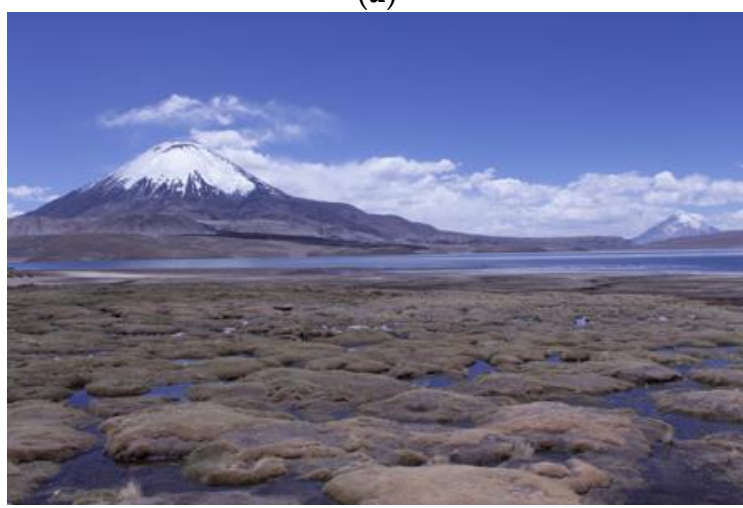

(c)

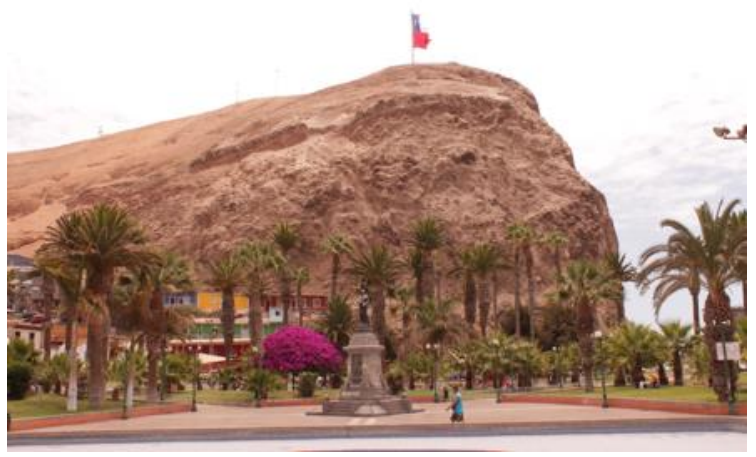

(b)

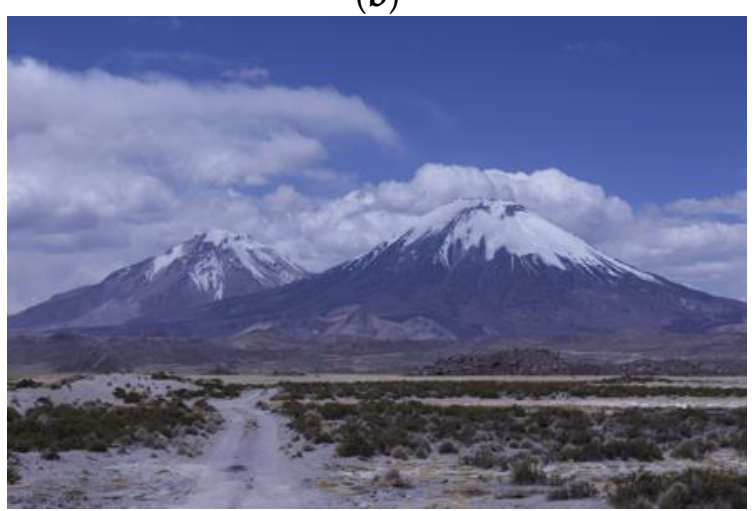

(d)

Figure 2. Representative locations in the Region of Arica and Parinacota: (a) "San Marcos" Cathedral, Arica; (b) "El Morro", Arica; (c) Chungará Lake; and (d) Payachata Mountains.

\section{Part I}

\subsection{The Aymara people and their historical relationship with the region of Arica and Parinacota}

The origin of the Andean populations is dated more than 10,000 years ago. Since that time, populations of hunter-gatherers arrived in the lands of northern Chile and settled along the coast and in the Pacific coast's valleys. Gradually, and due to environmental pressure (mainly periods of drought), these populations began likely to develop crop practices and domesticate animals around the year 2,000 BC. these populations started establishing themselves in small villages and hamlets occupying the different ecological 
floors of the northern valleys of Arica, currently concentrating on the territory that includes the region of Arica and Parinacota [7].

Evidence indicates that during the $11^{\text {th }}$ century, there was a village cultural complex made up of fishers, farmers, and shepherds called "Cultura Arica". This cultural complex controlled from the mountains of the Precordillera of Arica to the coastal areas. Evidence suggests a commercial and cultural interaction between the Arica Culture and the Carangas populations located in the central Andean highlands [8]. From the beginning, the original populations developed an intense exchange and occupied territories in the diverse ecological floors to complement the nuclear centers' economy [7].

During the Inca period, the territories were organized according to the already established structure, so the Lords or "Caciques" of each expanse submitted themselves to a system of tributes to the Inca, where each Lord had to deliver goods in exchange for protection, trade, participation in ceremonies, among other aspects. There is no doubt that the Inca influence was essential for constructing the Aymara people, both on a socio-cultural, economic, and political level. Today, it is recognized that most of these people's identity refers to this period as a foundational milestone and the origin of things [7].

After the Spaniards' arrival, the entire territory was organized into Viceroyalties, Kingdoms, and Townships [9]. The Aymaras then put in place "Amparos de Tierras" to safeguard the ancestral property titles. The conquerors granted such documents only to rearrange the territory based on taxes. Thus, having lands implied, therefore, the obligation to pay tribute to the king. This entire period was not exempt from abuses, especially from the $17^{\text {th }}$ century onwards, when the conquistadors and the church carried out a process called the Extirpation of Idolatries, which was carried out not only for religious purposes but rather for administrative and control objectives [7]. This process resulted in a gradual return, or rather refuge, for the Aymara people who settled in the valleys and the Precordillera.

After Chile, Peru, and Bolivia's independence, a new adjustment for this ethnic group began. The consolidation of the Republics of Peru and Bolivia brought with it the fracture of the Aymara territory. Peru took all the territory to the North and East of Lake Titicaca, and the rest became part of Bolivia. After the War of the Pacific (1879-1882), Chile annexed the territories of Arica and Parinacota and Tarapacá (formerly Peruvian) and Atacama (formerly Bolivian) [10], primarily made up of Aymara, Quechua, and Lican communities, which again implied a process of adaptation of these people to a new socio-cultural and territorial order.

The Chilean State carried out actions to cut ties between the "Chilean" Aymara communities and neighboring countries through a process of "forced Chileanization." From the annexation until 1990, it is considered a "first period," marked by the State's action, with a high military contingent and the establishment of public primary education schools. Later, there was a reorganization of municipalities during the military dictatorship. During this period, the ancestral organization of territories was not taken into account, and family community property was transformed into private property, and the Aymaras had to buy back their ancestral lands [10].

From the end of the 20th century to the present day, the second period is characterized by the "ethnic" resurgence. The approval of the Indigenous Law, 19,523 in 1993, provides a new legal framework that gives tools for developing native peoples. Furthermore, with the migration process of Aymaras to the cities, urban indigenous elites have emerged that, rather than erasing their identity, contributed to their strengthening [10]. 
Concerning the connections of Aymaras in Chile, Peru, and Bolivia, these have always endured due to the steady exchange between the three countries. In the case of the exchange with Chile, this has been mainly from the Oruro altiplano to the agricultural valleys and coastal cities. Modernization changed the type of exchange, now more similar to capitalist labor and economic exchanges, but always with a hint of the past, especially regarding celebrations and festivities [7].

It is important to explain that the Aymara identity, since the creation of the national states, has been debated between that of their people (derived from the long centuries of shared history) and each of their countries' identity, imposed since the creation of the Republics.

\subsection{Contextualization of the work}

The previous paragraphs support the notion that the Aymara people have been the ones who for millennia have occupied and developed their history of life as an ethnic group in the different ecological floors present in the current Region of Arica and Parinacota. With current data, this work is intended to emphasize the importance of these people in developing and maintaining peasant agriculture in the different coastal valleys and the Chilean altiplano. Although archaeological literature indicates that fishers occupied the Azapa Valley from the coast of Arica to carry out the first agricultural practices [11], in this study, the Lluta River Valley, the Precordillera, and the Codpa Valley will be used as the object of study. Given its soil and climatic conditions, these conditions do not allow the implementation of large systems of intensive production, which differentiates it from the Azapa Valley, and has allowed the maintenance of small agriculture more rooted in ancestral customs.

The three units correspond to rural areas, with economic activities focused mainly on agriculture and a lesser extent on livestock. The Lluta River Valley sector has an eminently agricultural economic vocation with some remnants of livestock activity, focused mainly on agro-industrial production of national scope. The upper sectors of the valley have a domestic production. The Precordillera of Arica is an agro-livestock sector - although livestock is increasingly reduced - whose production is for self-consumption, and the surpluses are partially destined to the local and regional market. Finally, the Codpa Valley stands out for developing a small-scale fruit activity, which in part supplies the regional market.

\subsection{The current socio-cultural context of the Aymara people in the region of Arica and Parinacota}

In demographic terms, Arica - Parinacota stands out because its regional population is strongly concentrated in the commune of Arica with $97.7 \%$. The remaining $2.3 \%$ is dispersed in the extensive rural communes. In effect, within the selected sectors, the main residential areas do not exceed 200 inhabitants [12]. The ethnic composition of the population, according to the 2013 CASEN survey, 54,075 people in the region of Arica and Parinacota declared themselves to belong to an indigenous people, which corresponds to $31.5 \%$ of the regional population, the second-highest percentage of indigenous people after the Araucanía region. Of the total indigenous population, $88.1 \%$ belong to the Aymara people, reaching 47,640 individuals, the region with the largest Aymara population at the national level [13]. Rural areas contain a strong contingent of Aymara population: Putre $52.9 \%$ and Camarones $61.9 \%$ [12]. The case of the Lluta Valley is different from the other sectors in terms of the indigenous population. From the coastal area to Poconchile, there is a significant degree of mestizaje, with many migrant workers of Bolivian and Peruvian origin who ascribe to an ethnic Aymara or Quechua identity. In the sector of Chaupiyunga, the majority of the population is Aymara, belonging to families considered to be native to the valley and who have ancestrally inhabited the territory. These families are constituted as Indigenous Communities under Law 19,253. 
Another particularity of the region concerns population flows and movements. It is possible to detect historical patterns of territorial occupation based on constant movements between different ecological floors [14]. However, in the middle of the $20^{\text {th }}$-century, transformations occurred that profoundly altered the regional demographic dynamics. In the 1950s, the Free Port was decreed in Arica (1953) as part of a plan to promote the development of the area, which stimulated trade and, therefore, increased travel to the city by the Andean population. Additionally, the "Junta de Adelanto" (1958) was created, which began to carry out infrastructure works, including building road networks, which in the late 1960s connected the interior towns with the coastal areas. In this way, the Andean community moved massively to the city of Arica, since it presented great commercial opportunities and, in turn, offered services desired by the population, such as diversity of jobs, health, and education at all levels [15]. This demographic change led to the generation of what has been called the "regionalization of Aymara society" [16]. New political, economic, and social relations emerged due to the expansion and extension of the Andean population's action area. At present, most of the Indigenous Communities members do not reside in their towns of origin but in Arica. Despite this, the inhabitants maintain strong ties that unite them to their territory and reproduce forms of organizing their social life in the city based on their communities of origin.

Moreover, it is important to consider that, at the same time that this regionalization of Aymara society was occurring, the old community territories were also being fragmented. This fragmentation was prompted by the Neighborhood Councils' creation that extended into the interior towns between the 1960s and 1970s, which concentrated civil activities in the small centers of residence, no longer frequenting the old "Markas" or towns established during the colonial period. This territory disintegration intensified in the 1990s, through the constitution of the Indigenous Communities that were promoted by the new institutionality of the National Commission for Indigenous Development CONADI. Participation in Indigenous Communities has the particularity of being exclusive, preventing membership in more than one Community. This fact has had the effect of increasing localist identity concerning the Indigenous Community. In some cases, a single-family formed an Indigenous Community since the legislation allows a minimum of 10 people with a common ancestor to be constituted a community. This legislation has also tended to community entities fragmentation.

Currently, indigenous communities are characterized as trans-local, with the understanding that for their collective realization, they function in an interdigital manner between the community territories and the city of Arica [17]. The majority of community members live in the city. However, they are constantly on the move - whether daily, weekly, or seasonally - to their villages for productive reasons (planting and harvest seasons, cleaning of canals), religious reasons (local and regional festivities), or administrative reasons (calls from the municipality, neighborhood council, or indigenous community). These structural dynamics of the Andean populations must be considered in any strategy of involvement with the communities. Despite this translocation, it must be considered that the regional demographic trend is towards the depopulation of rural localities, with permanent residents mostly belonging to the elderly age category [12].

As for the forms of association and social articulation, it is possible to find diverse organizations of a functional and territorial type, some of which have their origin in the community bases. Others emerged from the State or private entities, which continuously interact intermittently with the local community members. Some outstanding organizations distinctive of the peoples are Indigenous communities with legal status under Law 19,253, Neighborhood Councils, Mothers' Centers, Elderly Clubs, irrigation communities, and productive associations of farmers, ranchers, and tourism, cultural, heritage, and religious associations. On the other hand, some of the relevant public organizations with a 
presence in the territory are DIDECO, INDAP, PRODESAL, CONADI, PRODEMU, SAG, and INIA. As for the private institutions, the work carried out by the Altiplano Foundation in the restoration of churches and facades of the Andean villages (Poconchile, Socoroma, Belén, Ticnámar, Tímar, Codpa) stands out. This foundation has extensive networks and adequate management capacity and is currently being positively evaluated by the people (information obtained by the company Vincula S\&C as part of this research, 2018). The Foundation for the Overcoming Poverty is Also present. Through "Servicio País", it has intervened in various sectors of the region, with a positive valuation among people (information obtained by the company Vincula S\&C as part of this research, 2018).

\subsection{Agricultural Contextualization of the Aymara people in the Region of Arica and Parinacota}

From the agricultural perspective, based on the VII National Agricultural and Forestry Census of 2007, ODEPA and the Origins Program prepared the report "Chilean Indigenous Agriculture: social and productive information according to ethnicity" [7]. Table 1 presents relevant information on indigenous agriculture in the region concerning farms and exploitation areas, while Table 2 shows this information by ethnicity.

Table 1. Farms, Area and Regional and Indigenous Utilized Area

\begin{tabular}{cccccc}
\hline Category & $\begin{array}{c}\text { Indigenous } \\
\text { total }\end{array}$ & $\begin{array}{c}\text { Regional } \\
\text { total }\end{array}$ & $\begin{array}{c}\text { Non-indig- } \\
\text { enous total }\end{array}$ & $\begin{array}{c}\text { \% Indige- } \\
\text { nous over } \\
\text { regional to- } \\
\text { tal }\end{array}$ & $\begin{array}{c}\text { \% Indige- } \\
\text { nous over } \\
\text { tal }\end{array}$ \\
\hline $\begin{array}{c}\text { No of exploitations } \\
\text { tonal to- }\end{array}$ & 1,237 & 2,497 & 1,260 & $49,5 \%$ & $2,3 \%$ \\
$\begin{array}{c}\text { Agploitation surface (ha) } \\
\text { in exploitation (ha) }\end{array}$ & $180,330,9$ & $550,143.4$ & $369,726.3$ & $32,8 \%$ & $0,3 \%$ \\
\hline
\end{tabular}

Source: Own elaboration from data of [7].

Table 2. Farms, Area and Surface Used in Arica and Parinacota by Ethnicity

\begin{tabular}{ccccc}
\hline \multirow{2}{*}{ Area } & Ethnicity & $\begin{array}{c}\text { No Exploita- } \\
\text { tions }\end{array}$ & $\begin{array}{c}\text { Exploitations } \\
\text { Surface (ha) }\end{array}$ & $\begin{array}{c}\text { Used agricul- } \\
\text { tural surface } \\
\text { (ha) }\end{array}$ \\
\hline Cordillera & Aymara & 146 & $113,524.3$ & $92,863.2$ \\
\cline { 2 - 5 } Desert & Aymara & 722 & $2,964.1$ & $2,215.9$ \\
& Quechua & 1 & 0.8 & 0.4 \\
Precordillera & Other & 12 & 27.2 & 17.0 \\
\cline { 2 - 5 } & Aymara & 356 & $63,814.7$ & $63,311.5$ \\
\hline Arica and Parinacota & & 1,237 & $180,330.9$ & $158,408.2$ \\
\hline total & & & & \\
\hline \% Aymara above total & & $98.95 \%$ & $99,98 \%$ & $99,99 \%$ \\
\hline
\end{tabular}

Source: Own elaboration from data of [7].

Considering that $88.1 \%$ of the indigenous population in the region belongs to the Aymara people, the data in Tables 1 and 2 closely represent ethnic agriculture in the Region of Arica and Parinacota. Approximately half of the region's farms are indigenous $(49.5 \%)$, and indigenous agriculture represents only $32.8 \%$ of the total area of farms in the region, so land use by ethnic agriculture is rather complete (not partial). This data is proven by the fact that $90.2 \%$ of the agricultural surface used in the region of Arica and 
Parinacota corresponds to indigenous farms. Of the latter, Aymara people are predominant in the region (Table 2), with $98.95 \%$ of the number of farms and almost $100 \%$ of the agricultural area used. Therefore, the other half of the farms, those classified as non-indigenous, occupy only $9.8 \%$ of the utilized agricultural surface, with an average size of 13.6 hectares per farm, in contrast to the 128.1 hectares of agricultural surface of indigenous farms.

Institutionally, small and medium-scale rural agriculture is publicly addressed by the Ministry of Agriculture through the Institute for Agricultural Development (INDAP). This entity estimated 2,267 rural family agriculture farms in the Region of Arica and Parinacota [18]. In 2016, the institution had a total of 956 users, of which 844 belonged to indigenous people. The average age of the users is 57. INDAP's main programs that work with native peoples are the Indigenous Territorial Development Program - PDTI - and the Local Development Program - PRODESAL. In 2016, PDTI had 346 users from indigenous peoples, and PRODESAL a total of 106 or a total of 452 users. Given that these two programs are the most relevant and longest running, it can be deduced that of the 1,237 indigenous farms in the region (Table 1), INDAP covers $36.5 \%$. If one considers the specific technical assistance and care provided to users of indigenous peoples served by INDAP in 2016 , coverage is $68.2 \%$.

\section{Part II}

\subsection{Agricultural Contextualization of the Aymara People}

The Aymara people's agricultural characterization is presented from data disaggregated by region, including other regions with an Aymara presence (Tarapacá Region and Antofagasta Region). These data of characterization of the Aymara agricultural producers are considered representative of the Region of Arica and Parinacota, exceptionally, for their high presence over the total.

The total number of Aymara agricultural producers in Chile is 2,729. In the Arica and Parinacota Region (Table 2), 1,224 Aymara farms are registered, which means that this region concentrates $44.85 \%$ of Aymara agriculture and $49.26 \%$ of its used agricultural area. In 2011, ODEPA and the Origins Program [7] characterized Chilean indigenous agriculture, both socially and productively, indicating that Aymara producers have a marked tendency toward old age, with $59 \%$ being over 51 years old, and $19.6 \%$ between 41 and 50 years old. On the other hand, they maintain that $61 \%$ of Aymara farmers do not live on the farm, which is also a risk due to transportation difficulties and limited time for field visits. This fact can be partially explained by the fact that $41 \%$ of these farmers own two or more land plots, and $24 \%$ own three or more land plots.

Another relevant point is the level of schooling of Aymara producers, perceiving that $10.9 \%$ have no schooling, and $61 \%$ have a primary or preparatory level. Twenty percent of them have a medium level of education or humanities. This low schooling level is considered a potential risk for establishing farmer networks in terms of communication and information.

\subsection{Characterization Sector 1}

- Lluta: The Lluta River valley is a hydrographic basin of more than $150 \mathrm{~km}$ long, having its source on the slopes of the Tacora volcano on the Altiplano floor, which gives it salinity and high boron content to the waters. The altiplano descends in a southwest direction, capturing numerous tributaries of the pre-cordillera zone, allowing it to have a permanent flow of water that flows into the sea. The lower zone considers the Lluta River's mouth to about $80 \mathrm{~km}$ towards the interior of the valley, approximately at an altitude of 2,500 meters above sea level. It corresponds to the most significant agricultural 
potential area because it has large areas for crops and a climate without harmful frosts for crops. In turn, the lower zone can be divided into three ecological sectors: coastal valley, fertile valley, and intermediate valley or Chaupiyunga [19]. The coastal valley comprises about $10 \mathrm{~km}$ from the mouth of the river to a height of 250 meters inside the valley. It is a sector of sandy, stony, and poorly drained soils, which hinders agricultural development. The fertile valley stretches from Morro Negro to the Churiña Angostura, about $45 \mathrm{~km}$ inland and at an altitude of approximately 950 meters above sea level. It is a sector suitable for agriculture due to the basin's width $(2-3 \mathrm{~km})$ and the better drainage of the soils. The climate presents high solar radiation, warm temperatures, and low cloudiness, which, as a whole, favors the development of agricultural activity throughout the year. The intermediate valley, or Chaupiyunga, is located between Churiña and the town of Jarinmalla, about $80 \mathrm{~km}$ inland from the valley and at an altitude of 1,800 meters above sea level. The ravine narrows, so cultivation terraces have been made to allow agriculture and, in turn, to withstand the constant erosion caused by the river. The climate is drier and less cloudy than the productive sector, with a more marked thermal oscillation due to the increase in altitude.

- Poconchile: it is a town located in the fertile valley of the low zone of the hydrographic basin of the Lluta River. According to the 2002 census data, 115 people reside there, but this figure has likely increased to date considering expanding residential areas in the sector. The majority of people are dedicated to agricultural activity, either as salaried workers or as owners of their land, with the former being more represented, a situation probably associated with the establishment of haciendas in the lower sector of the valley since colonial times. According to those interviewed, there is no indigenous community in Poconchile that represents the sector's entire population. There are some communities in neighboring areas, corresponding to families of between 10 and 25 people who have inhabited those territories for many years and are oriented to satisfying their members' particular interests, generally related to agricultural activities in the valley.

Moreover, Poconchile has a Neighborhood Council, an organization that aims to socialize and apply for small cultural or productive projects, but with little impact on one of the activities that most interests the inhabitants, agriculture. The organization with the validity of bringing together farmers from the Poconchile sector is the "Asociación Gremial de Agricultores del Valle del Río Lluta". This association gathers farmers from the coastal sectors to the upper reaches of the valley in Vilacollo. Its declared objective is to "promote the rationalization, development, and protection of its members' agricultural activity. "It is a functional organization for productive work, without dealing with specifically indigenous issues. The "Gremial" has more than 70 active members. However, it presents difficulties in convening its meetings, typically meeting with 15 to 20 people. Sessions are convened by the leaders when requested by institutions that wish to work with them or when a director or regular member requests it, so they do not have preestablished periodic sessions. They are permanently in contact with the institutions in charge of agricultural development in the area (INDAP, INIA, CORFO).

- Molinos/Chapisca - Sora - Challallapo: These communities are located in the intermediate sector or Chaupiyunga. The town of Molinos corresponds to a housing complex (32 houses) surrounded by agricultural areas in the basin of the middle sector of the Lluta River (Figure 3). It is the most populated hamlet in this sector with 39 residents according to the census, but according to its leaders, currently, that number does not exceed 20 people. Nevertheless, it is remarked that a significant floating population that moves between Arica and Molinos for productive reasons intensified during the months of sowing and harvesting crops. From Molinos to the upper sectors of the valley, a dispersed residential occupation pattern can be observed, with houses with agricultural areas separated from each other by long distances. The next town in the sector is Sora, which is currently occupied permanently by only a few families. According to the 2002 census, the total 
population of residents in all towns from Molinos to Vilacollo (the last inhabited place) does not exceed 20 people. Despite this depopulation, its current inhabitants still carry out agriculture with traditional canalization, irrigation, and soil management practices. The indigenous communities of this section of the valley are Challallapo Indigenous Community (which incorporates Sora); Chapisca Indigenous Community; Junta de Vecinos and Aguas de Molinos Community; Inti Marka Indigenous Community of Molinos. The most active of these four organizations is the "Junta de Vecinos de Molinos", mainly because more people reside there. Concerning Molinos, the Neighborhood Council and the Indigenous Community are composed of practically the same people, but they meet for different purposes. The former is concerned with aspects related to the village organization, and the latter is oriented towards the application of competitive projects in pursuit of productive benefits.

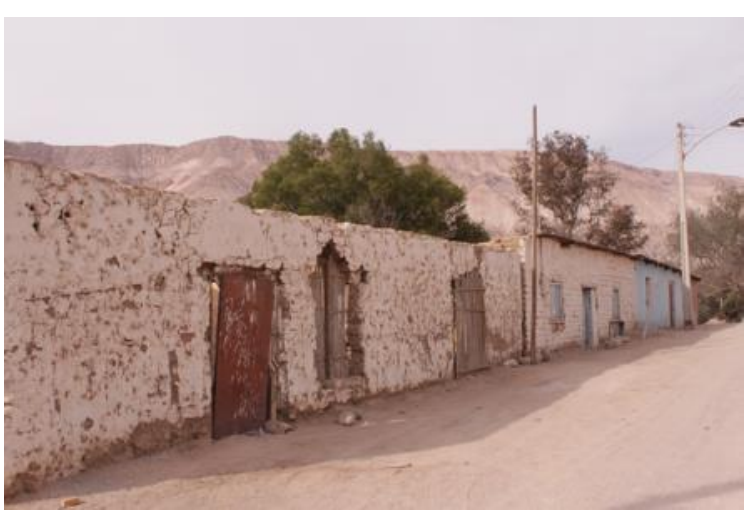

(a)

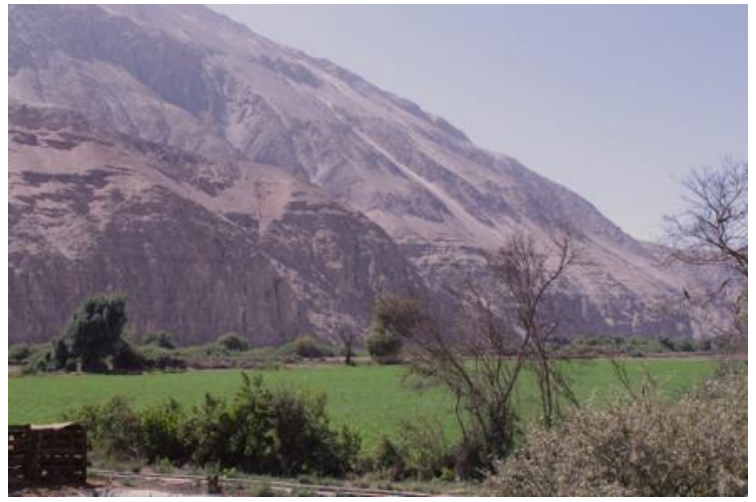

(b)

Figure 3. Molinos Town: (a) Some houses; (b) Alfalfa crops.

The functions of all the indigenous communities in the sector are linked to agricultural and livestock activities, the main occupations of their members (although livestock farming is becoming less prevalent in their activities). Their efforts are oriented towards the construction and repair of canals, subsidies for agriculture, improvement of services such as roads, electricity, and others. These organizations have approval and legitimacy to act as interlocutors for their territories with government institutions or authorities. In accordance with the above, the four organizations' leaders indicate that they maintain constant relations with their territorial bases and discuss before making any decision. Although each organization meets separately to resolve internal conflicts and apply for projects that concern them in their community's territory, they maintain fluid communication to face larger projects that involve extensive stretches of the intermediate sector of the Lluta Valley. Therefore, even though each Indigenous community is autonomous concerning the others, it seems that no statute indicates a power to make decisions jointly.

\section{Characterization Sector 2:}

- $\quad$ Precordillera: The Precordillera or Sierra is located between 2,500 and 3,700 meters above sea level, presenting an abrupt and irregular relief due to tectonic forces' action, with long mountain ranges that are split by ravines from where springs that supply water to the Lluta River are born. The climate corresponds to the classification of the marginal desert of height, characterized by scarce annual precipitations, concentrated between the months of December and March, and with a dry quite prolonged station, which, as a whole, allows the proliferation of significant flora and fauna, being a propitious space for the development of agriculture and animal domestication. Due to the altitude, there are strong thermal oscillations, with temperatures below $0{ }^{\circ} \mathrm{C}$ at night and above $20^{\circ} \mathrm{C}$ during the day. In the region of Arica and Parinacota, there are two longitudinal ranges, one on the western side, called "Sierra de Guaylillas", and the other on the eastern side, higher 
than the previous one and forming a wall towards the highlands, called "Cordillera Central" or Chapiquiña. It is in the Sierra de Guaylillas, between 3,000 and 3,300 meters above sea level, where all the Precordillera towns are located. However, it should be considered that the cultivation sectors are below and above this altitude in consideration of the steep slopes of the ravines where the populated areas are located $[4,20]$.

- Socoroma: It is a town located in an area considered the head of the valley, in the Socoroma ravine (Figure 4), whose waters are a tributary of the Lluta River. The populated town is located at an approximate altitude of 3,000 meters above sea level, but the territory contains crops at different altitudes since the ravine descends abruptly into the valley, generating varied microclimates and agricultural possibilities [21]. The community territory of Socoroma is a vast extension that includes the agricultural sectors and the grasslands of the hills, in which the localities of Zapahuira, Murmuntani, Epispacha, and Chusmiza are registered. Although these localities recognize that they belong and form part of Socoroma territory, due to the formation of independent indigenous communities under the eaves of the Indigenous Law, there has been a tendency to merge the community territory. According to census data, 76 people live in the town, but observations in the field show that no more than 30 people live there, who are mainly engaged in agriculture, since only two families supplement their economies by grazing sheep, and tourism is still too incipient to make a living from it. In Socoroma, the two most representative institutions of the town are the "Junta de Vecinos" (Neighbors' Board) and the Indigenous Community of Chukuruma (Aymara name that was Spanishized to Socoroma). The Neighborhood Council deals with issues that specifically concern the Precordillera people and is widely attended by permanent residents, typically meeting once a month when work on the farms is completed. The Indigenous Community, on the other hand, deals with more global issues, and in recent years its discussions and projects have had political overtones since many of its members have been trained in issues of indigenous heritage and rights and have also faced conflictive situations in their territory that have made them aware of their ethnicity.

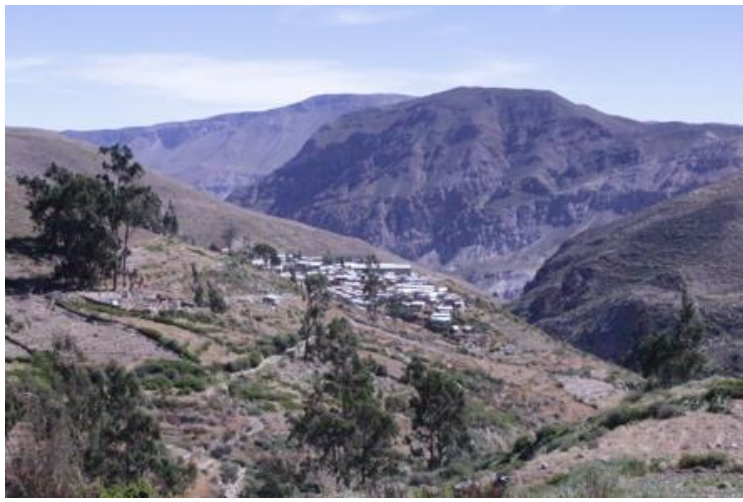

(a)

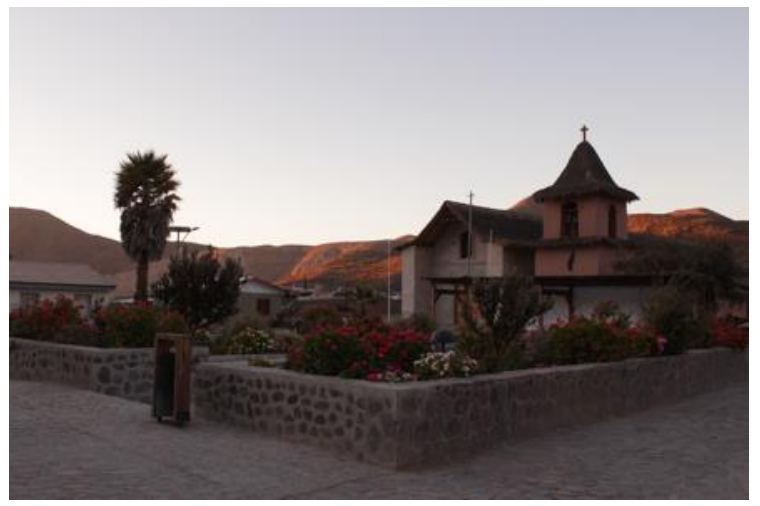

(b)

Figure 4. Socoroma Town: (a) View of the town; (b) Square and Church of Socoroma.

Nevertheless, the calendar of religious festivities, very numerous in Socoroma, must be taken into account. Despite internal fissures resulting from rivalries between families, it presents a strong community cohesion, acting based on decisions agreed upon by representative organizations. An emblematic case was the mobilization to end the sanitary landfill in the province of Parinacota, located in Socoroma territory, in the Tojraje sector, a situation that activated the organization of the community, achieving that the authorities stopped the internment of garbage in the landfill. From this perspective, it can be seen that there is a high capacity for management and organization among the "Socoromeños" when common goals or objectives are set. 
- Chapiquiña: The establishment of Chapiquiña as a town is relatively recent and was founded during the time of the region's Chilean occupation on an old ranch dependent on Pachama. The town was established in the sector of Chapiquiña with geopolitical aims, concentrating the population of the zone that was dispersed in the territory and installing state institutions to control and to deepen the process of chilenization. For this reason, the families of Chapiquiña and Pachama are fundamentally the same, with Pachama becoming the ceremonial sector (where the Church is located and community celebrations are held), while Chapiquiña is in the residential sector [22]. The temperature of Chapiquiña is slightly lower than the rest of the Precordillera towns. Unlike these towns, Chapiquiña was located in an esplanade and not on the slopes of hills or in a ravine, leaving it exposed to winds that lower the temperatures. Concerning the above, the area of cultivation of Chapiquiña is considerably smaller than that of Pachama, a town with sectors more protected from frost. According to the informants, the 2002 census registers 38 people residing in Chapiquiña; however, there are only about 10 people permanently in the town. The communal territory of Chapiquiña is divided into diverse sectors that have historically used different family trunks, which through the Indigenous Law, have formed independent indigenous communities. These are the organizations: Indigenous Community of Chapiquiña Sector Laco - Cosapilla (14 members), Indigenous Community of Copaquilla (40 members), Indigenous Community Pukara of Copaquilla (27 members), Indigenous Community of Chapiquiña (59 members). The latter is the one that convenes the communal members of the Chapiquiña and Pachama peoples, which is understood to be representative of the families present in the territory, since the other indigenous communities are dedicated to the application of specific projects for their sectors, such as water canalization, road repair, productive initiatives, and others.

- $\quad$ Belén: The town of Belén (Figure 5) is located at an altitude of 3,268 meters above sea level, $143 \mathrm{~km}$ away from the city of Arica at the head of Azapa Valley. Its location is strategic since it is in an area with abundant freshwater from numerous springs, with permanent water resources throughout the year. These conditions have been used since the beginning of the region's population by the first settlers because in a ravine of the sector were found the remains of old whereabouts of hunters - collectors, the rocky eaves of Tojo Tojone, approximately 8,000 years old. Belén has large areas of cultivation, from high areas of the territory to others boxed in by the ravines towards the lower areas [23]. According to the census, 70 households and 51 people reside in the town, but no more than 20 people live permanently in the town. The two public services present in the town are the rural post and the primary school. The town of Belen has several organizations, some associations of cultural type that work preferably in the city of Arica and others mainly in the locality, as the case of the Club of the Elderly, the Community of Irrigators, and the Meeting of Neighbors. On the other hand, there are three Indigenous Communities with legal status and functioning in the territory: The Indigenous Community of Quipaquipani (17 members), the Aymara Tablatablane Indigenous Community of Belén (17 members), and the Indigenous Community of Belén (157 members), the latter being the most representative and considered by the communal people as "that of the people."
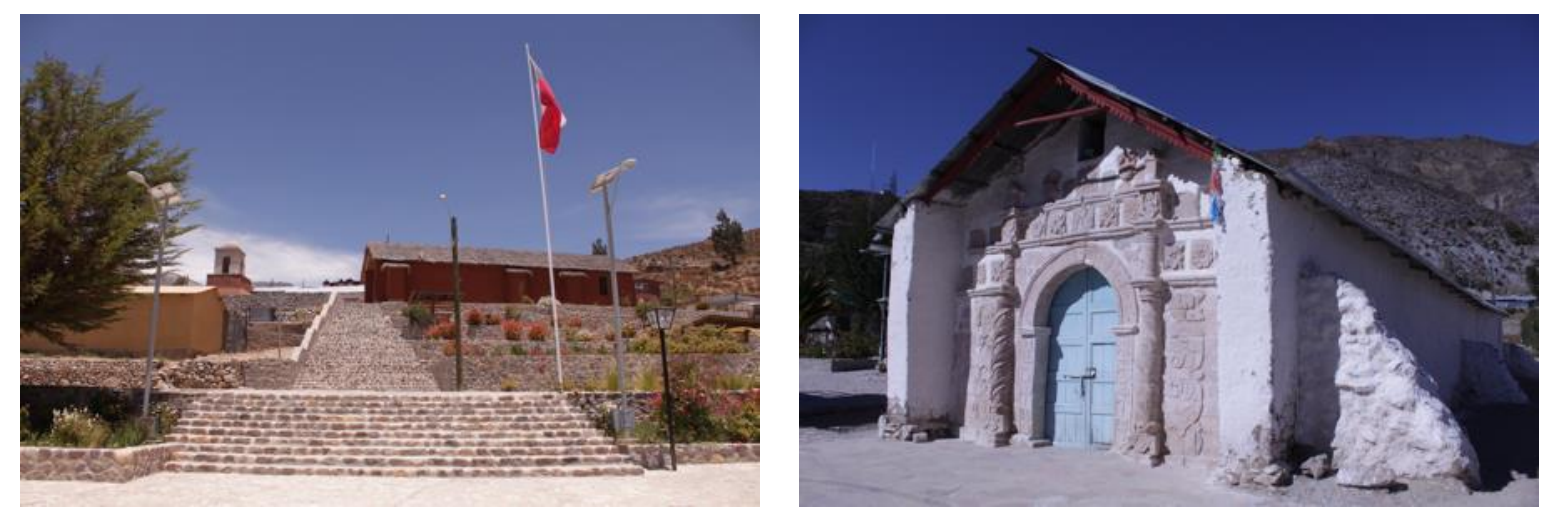
Figure 5. Belén Town: (a) Square of Belén; (b) Church of Belén.

In the case of this locality, the Indigenous Community of Belén is the space for dialogue and deliberation of matters that concern the whole of the people, having significant legitimacy to establish relations with different political-institutional authorities, under the understanding that the Indigenous Community is an organization that watches over the development and care of the people. Based on the validation that this organization has, its leaders have the mission of channeling information to the rest of the members.

- Ticnámar: This town is located at 3,200 meters above sea level and $135 \mathrm{~km}$ from the city of Arica. Its current location is recent, since an intense flood of the river in 1959 destroyed a significant part of the old town, so the community requested the authorities of Arica to move the town to the place where it is today, in a higher sector and distant from the riverbed. According to the 2002 census, 93 individuals reside there, but to the residents' estimates, about 50 people, including the students and workers of the town's boarding school. In geographical terms, the town is located in a ravine that belongs to the San José River basin, a ravine divided into different sub-basins (Oxa, Río Grande, Chucasiña, Patagua, and Tumaya) that feed the different irrigation sectors of the community with water resources. Its waters correspond mainly to subway outcrops and, seasonally, to the product of summer rains, since in this sector of the mountain range, there are no snow accumulations in the altiplanic sector [24]. There are three indigenous communities in Ticnámar, the Quechua community (not registered with CONADI in 2015); the Successional Community, formed from the family trunks of the typical indigenous people who acquired the community territory through a purchase from Cacique Diego Felipe Cañipa, the authority of the "Altos de Arica" during the colonial period; and the Aymara Indigenous Community of Ticnámar, formed in 1996 under Law 19.253.

\section{Characterization Sector 3:}

- Valley of Codpa. The town of Codpa is located $120 \mathrm{~km}$ from the city of Arica. The valley of Codpa is situated in the Quebrada de Vitor's middle sector, between the 1,700 (Ofragía) and 3,300 meters above sea level (Incauta), constituting the main agricultural space of the sector. Vitor's hydrographic basin is born in high the summits of the Central Mountain range of Chapiquiña, from where the waters descend by boxed gorges, maintaining a superficial course of runoff until the town of Codpa, from which it begins to diminish the availability of the hydric resource. In the summer months, the most significant increase in river flow occurs due to rainfall in the upper sectors of the mountain range, while the absence of precipitation during the rest of the year causes a decrease in flow, with October and December being especially critical for the lower sectors of the valley. In the Codpa valley, it is possible to distinguish two towns: Codpa and Tímar.

- Codpa. The town of Codpa (Figure 6) is located in the central sector of the valley of the same name, in a narrow and steep ravine, at an altitude of 1,870 meters above sea level and approximately $113 \mathrm{~km}$ from Arica. It consists of 61 homes and 159 people according to the 2002 census, representing the main populated town in the valley. In Codpa, some public services are concentrated destined to the needs of the valley's population, such as the rural post, the professional technical school, the civil registry, and the library, reason why a relevant percentage of people occupied in municipal works exists. However, most of the co-population is dedicated mainly to agricultural work and less and less to livestock (sheep and goats). One of the areas that has grown the most recently is tourism, which has an excellent projection for the coming decades, although it is still in its infancy. One of the most significant difficulties in developing sustainable projects over time is the significant lack of basic social services that still exist in the village, since, for example, there is still no electricity (motors supply it for a few hours a day), and there is no sewage network that 
could improve the living conditions of the population. The co-workers have formed many functional and territorial organizations, which meet both in the town and in the city of Arica. Some of them are cultural associations that are oriented to strengthen patrimonial and identity aspects of the town, like for example, the Religious Dance Moreno Mixto Hijos de Codpa, the Social, Cultural and Artistic Club Juventud Estrellas de Codpa, the Agrupación Querido Valle de Codpa or the Agrupación Cultural de Codpa. Others are productive, such as the Cultural Heritage Association of Pintatani Wine Producers of the Codpa Valley, the Indigenous Association of Tourism of the Codpa Valley, or the Indigenous Association of Agricultural Producers of the Commune of Camarones that includes different localities of the valley and the town of Tímar. According to their objectives and functions, these organizations are dedicated to resolving or developing specific issues, bringing together community members who have common interests, acquiring a partial representation concerning the people of Codpa.

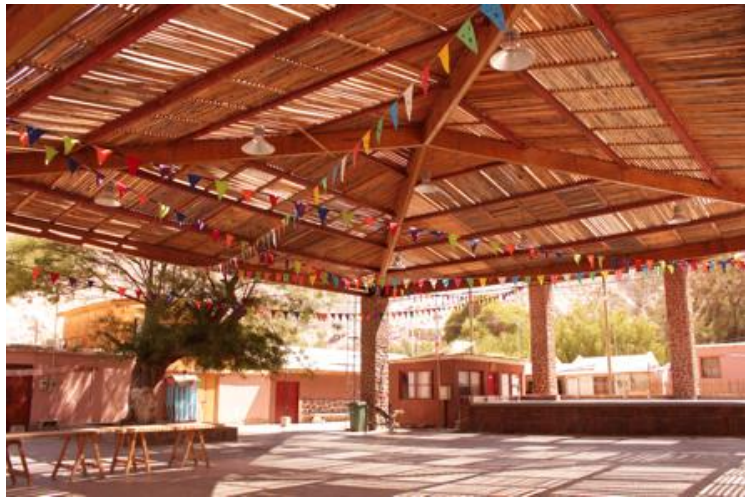

(a)

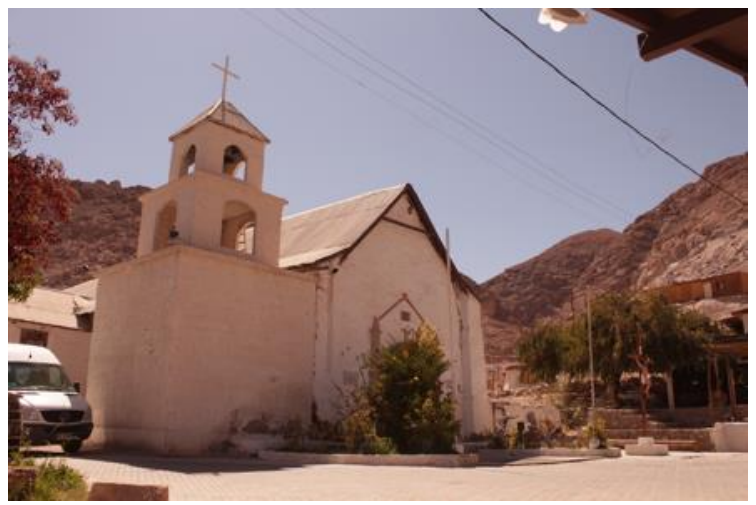

(b)

Figure 6. Codpa Town: (a) Square of Codpa; (b) Church of Codpa.

- $\quad$ Tímar. It is a populated locality of the Commune of Camarones, located in the Gorge of Heron or Calisama of the sector precordillerano (pre mountain range sector), to a height of 2,250 meters over sea level and distant of Arica to approximately $90 \mathrm{~km}$. It corresponds to an oasis irrigated by slopes that emerge from different sectors of the ravine, which are filled due to summer rains and thaws and the presence of water tables. The locals distinguish two crucial sectors, the Pueblo (high sector), where the nucleus of the town is located, and the Quebrada (low sector), where there are essentially areas of cultivation destined for fruit trees [25]. Tímar presents a microclimate due to geographic particularities: being located in a narrow ravine with significant solar radiation and the absence of strong winds, they cause a high temperature considering the town's altitude.

Furthermore, due to its distance from the coast, it does not present maritime influence - the humidity of the camanchaca does not reach it - and due to its altitude, it does not present winter frosts, which makes it suitable for a diversity of crops. According to the census of 2005 [12], Tímar comprises 25 houses and 17 residents, but less than 10 people live there permanently. However, like many other communities, the resident number varies depending on the season and the requirements of agricultural activity, spending time in the town and city of Arica.

\section{Part III}

\subsection{Agricultural Outlook and Projections}

A new approach to agricultural development in the coming years should be based on the economic development of agriculture, satisfying local and regional markets, 
proposing the improvement of some horticultural products (Figure 7) and others derived from livestock (cheese) to introduce them to a broader market. About $30 \%$ of the cultivated area in the Lluta Valley is covered by pasture, mainly alfalfa, for local livestock consumption to maintain an incipient livestock production. There are two or three productive units dedicated to producing sheep's milk and the remaining small units dedicated to goat's cheese production. However, they require the incorporation of technology and the improvement of production.

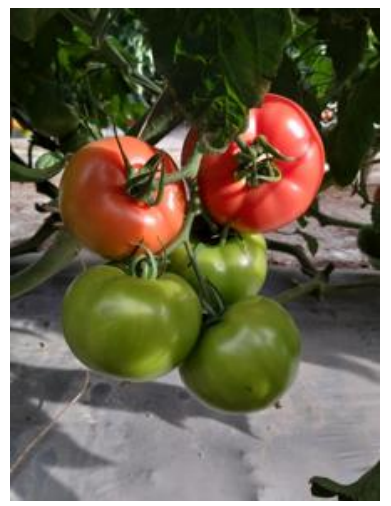

(a)

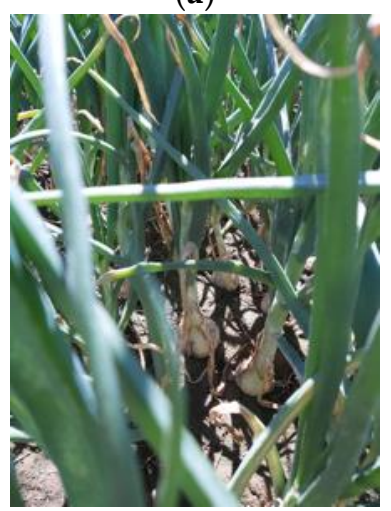

(c)

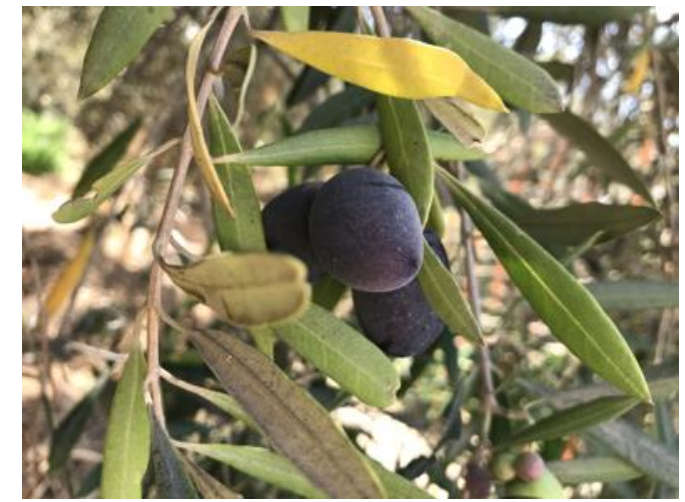

(b)

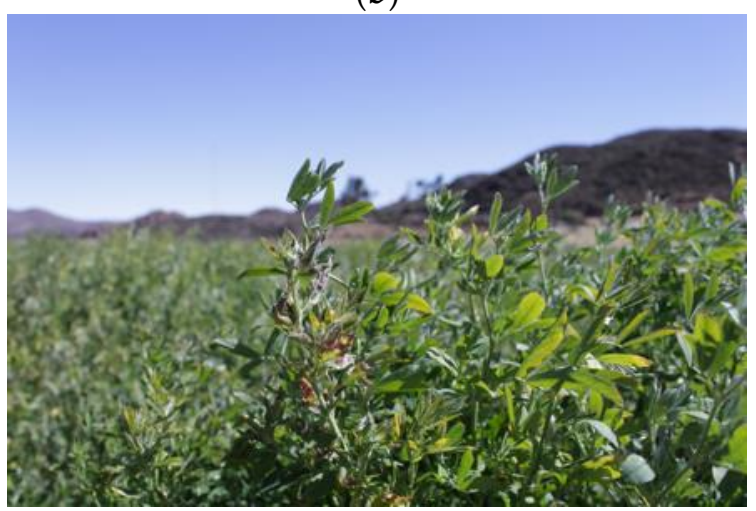

(d)

Figure 7. Agricultural goods produced in the Region of Arica and Parinacota: (a) Tomato; (b) Olives; (c) Onions; and (d) Alfalfa.

Considering the Lluta Valley's agro-ecological particularities, mainly the low quality of irrigation water, which has high boron content, the horticultural development is focused on "choclero" corn production cv. lluteño (adapted to the saline boric conditions of the Lluta Valley), onions, garlic, and, lately, tomato. According to Tapia and Vega [26] and Torres and Acevedo [27], the limiting factors focus on technical crop management deficiencies, training in horticultural management and management, and alternative shortages to diversify production, making it necessary to improve these problems promptly. One example to consider is the recovery of the "Poncho Negro" tomato crop, which, according to Angel et al. [28], has good production levels and organoleptic characteristics that make it attractive for production and marketing.

Another contribution, which should be integrated into the regional economy, is the camelid livestock, currently developed by Aymara farmers in the foothills and highlands of Arica, who keep knowledge and experience required for this millennium. Nevertheless, it would be necessary to advise in such aspects as production and commercialization of 
the derivatives of this cattle resource and genetic improvement of the species, among other aspects.

Based on the Arica and Parinacota region's data analysis provided by archaeology and ethnohistory, it is vital to propose botanical species' rescue. This action would help safeguard the plant's genetic heritage of some endemic or native plants domesticated 4,000 years ago, marking the beginning of food production, such as corn, sweet potato, potatoes, chili, jíquima, cassava, among others. It corresponds to species whose genetic diversity should not be lost but be part of the plant heritage of our desert valleys, rescuing their role in food and as part of the surplus production that farmers of the past used in the exchange of products with populations of other Andean regions, thus marking the agricultural economic identity of the Arica valleys.

It is a priority to develop an area or research center concerned with safeguarding the genetic heritage to move forward in achieving the objectives outlined in the previous paragraph related to the conservation of pre-Hispanic plant genetic diversity. This unit of conservation, i.e., center, should work next to a museum or botanical garden, where the vegetal species are exhibited and show their potential in the feeding, promoting, this way, the investigation, education, and recreation between the visitors. The idea of this botanical garden is that it meets the minimum requirements of the "International Council of Museums," which, in addition to educating on issues related to flora and biodiversity conservation, can contribute to the change in attitude necessary for society as a whole to understand the importance of conservation, within the framework of sustainable development. The vast microbial genetic patrimony should have a special mention, practically unknown and full of valuable resources that could solve not one but several demands of the contemporary society, avid of new genes and metabolites for use in the pharmacological, food, agricultural and biotechnological industry.

Author Contributions: Work conceptualization, G.S., I.M., D.C. and P.M.; Investigation and data curation G.S. and I.M.; Review, G.S., I.M., and P.M; Draft preparation: G.S., I.M., and P.M; Draft editing G.S., I.M., D.C. and P.M.; Photography, P.M.; funding acquisition, G.S. and P.M. All authors have read and agreed to the published version of the manuscript.

Funding: This work was supported by the FIC-CORFO Project 13CEI2-21852; and the execution of the Project Co-execution Agreement between the University of Tarapacá and the University of California Davis Chile ("Decreto Exento" №00.451/2018).

Acknowledgments: This work was supported by the FIC-CORFO Project 13CEI2-21852; and the execution of the Project Co-execution Agreement between the University of Tarapacá and the University of California Davis Chile ("Decreto Exento" №00.451/2018).

Additionally, this manuscript was edited by Mr. Ricardo Reyes Reyes from Editing Office of University of Tarapacá.

Conflicts of Interest: The authors declare no conflict of interest.

\section{References}

1. Hidalgo, J. Complementariedad ecológica y tributo en Atacama (1683 - 1792). Estudios Atacameños, 1984, 7, 1-15.

2. Cereceda, P.; Errázuriz, A.; Osses, P. Atacama: Ocupación actual del desierto y del semidesierto de Chile. Estudios Geográficos 2009, Vol. LXX, 266, 41-77. DOI: 10.3989/estgeogr.0443.

3. Muñoz, I.; Choque C. Interacción y cambio social: un relato arqueológico e histórico sobre las poblaciones que habitaron los valles precordilleranos de Arica durante los siglos X al XII D.C. Historia (Santiago) 2013, Volume II, 421-44. DOI: 10.4067/S071771942013000200004.

4. Niemeyer, H.; Schiappacasse, V. Patrones de asentamiento incaicos en el norte grande de Chile. In: La frontera del estado Inca (Dillehay, T. \& Netherly, P., eds.), 1988, 141-180; Oxford: BAR International Series. 
5. Cornejo, L. Recursos hídricos y desarrollo socioeconómico en zonas áridas: importancia y perspectivas de nuevas tecnologías aplicadas al tratamiento de aguas naturales y/o residuales. Ingeniare. Revista Chilena de Ingeniería, 2009, 17(3):285-287. DOI: 10.4067/S0718-33052009000300001.

6. Muñoz, P.; Arismendi, M.; Cárdenas, S.; Cifuentes, B.; Venegas, F.; Sepúlveda, G. Diversity of culturable bacteria isolated from ancestral crops of Arica and Parinacota Region, Atacama Desert. Antonie van Leeuwenhoek, 2020, 113, 2123-2137. DOI: 10.1007/s10482-020-01482-7.

7. Apey, A.; López, I.; Gallegos, A. Agricultura indígena chilena: información social y productiva de la agricultura según etnia. Available online: https://www.odepa.gob.cl/wp-content/uploads/2012/01/Agricultura_indigena_chilena_2011.pdf (accessed on 15 October 2020).

8. Muñoz, I.; Chacama, J. Complejidad Social en las Alturas de Arica: Territorio, Etnicidad y vinculación con el Estado Inca, 1st ed.; Ediciones Universidad de Tarapacá, Arica, Chile, 2006, 392 p.

9. Cúneo-Vidal, R. Historia de la Fundación de San Marcos de Arica: Leyendas de Arica, Tarapacá y Atacama, 1st ed.; Edición Ignacio Prado Pastor, Arica, Chile, 1977; pp. 215-451.

10. Albó, X. Aymaras entre Bolivia, Perú y Chile. Estudios Atacameños, 2000, 19, 43-73. DOI: 10.22199/S07181043.2000.0019.00003.

11. Muñoz, 2010 Explotación de los ecosistemas húmedos por los tempranos agricultores prehispánicos del valle de Azapa. Idesia, 2010, 28, 2, 107-115.

12. INE. Ciudades, Pueblos, Aldeas y Caseríos. Resultados Censo 2002. Instituto Nacional de Estadísticas. Available online: https://dataspace.princeton.edu/handle/88435/dsp019g54xm55n (accessed on 11 September 2020).

13. Casen 2013: Pueblos Indígenas Síntesis de Resultados. Ministerio de Desarrollo Social. Available online: http://observatorio.ministeriodesarrollosocial.gob.cl/storage/docs/casen/2013/Casen2013_Pueblos_Indigenas_13mar15_publicacion.pdf (accessed on 23 July 2020).

14. Murra, J.V. El control vertical de un máximo de pisos ecológicos en la economía de las sociedades andinas. In: Murra, J.V. (Ed.), Formaciones Económicas y Políticas del Mundo Andino. Instituto de Estudios Peruanos, Lima, Perú, 1975, 339 p.

15. Pizarro, W.; Ríos, E. Entre franquicias y beneficios: una apuesta del gobierno para el desarrollo regional de Arica (1953). Diálogo Andino, 2005, 25, 101-111.

16. Gundermann, H. Procesos regionales y poblaciones indígenas en el norte de Chile. Un esquema de análisis con base en la continuidad y los cambios de la comunidad andina. Estudios Atacameños, 2001, 21, 1-15. DOI: 10.22199/S07181043.2001.0021.00005.

17. Gundermann, H.; Vergara, J. Comunidad, organización y complejidad social andinas en el norte de Chile. Revista estudios atacameños arqueología y antropología SURANDINAS, 2009, 38, 107-126. DOI: /10.4067/S0718-10432009000200008.

18. INDAP en cifras. Año 2017. http://www.indap.gob.cl/docs/default-source/default-document-library/indap-en-cifras-cierre2017.pptx?sfvrsn=0 (accessed on 23 July 2020).

19. Santoro, C.; Romero, A.; Standen, V.; Torres, A. Continuidad y cambio en las comunidades locales, períodos Intermedio Tardío y Tardío, Valles Occidentales. Chungara, 2004, Volumen Especial: 235-247.

20. Choque, C.; Muñoz, I. El Camino Real de la Plata. Circulación de mercancías e interacciones culturales en los valles y Altos de Arica (siglos XVI al XVIII). Historia (Santiago), 2016, 49, 1, 57-86. DOI:/10.4067/S0717-71942016000100003.

21. Castro, M. y M. Bahamondes, M. Control de la tierra en la cabecera del valle de Lluta. Revista Chilena de Antropología. 1988, 7:99113.

22. Leal, J. Narrativas territoriales de la comunidad aymara de Chapiquiña en los altos de Arica. Revista Chilena de Antropología, 2017, 36: 234-254. DOI: 10.5354/0719-1472.2017.47491

23. Jofré, D. 2003. Una propuesta de acercamiento al patrimonio arqueológico de la comunidad de Belén (Región de Tarapacá, Chile). Chungara, Revista de Antropología Chilena, 2003, 35 (2), 1 - 15. DOI: 10.4067/S0717-73562003000200013.

24. Platt, T. Experiencia y experimentación: Los asentamientos andinos en las cabeceras del valle de Azapa. Chungara, Revista de Antropología, 1975, 5, 33-60.

25. Humire, V.; Nancuante, V.; Véliz, L. Influencias y cambios en la estructura económica andina: estudio de dos pueblos, Timar y Ticnamar entre los años 1930-1970 (Tesis inédita para optar al título de profesor de historia). Universidad de Tarapacá, Arica. 2000.

26. Tapia, F.; Vega, B. Tipologías de agricultores en el valle de Lluta. In Estudio Básico: Investigación Silvoagropecuaria de Innovación en la I Región, 1st ed.; Tapia, F., Ed. Boletín INIA: Arica, Chile, 2009; Volume 197, pp. 52-63.

27. Torres, A.; Acevedo, E. El problema de salinidad en los recursos suelo y agua que afectan el riego y cultivos en los valles de Lluta y Azapa en el norte de Chile. IDESIA, 2008, 26(3), 31-44. DOI: 10.4067/S0718-34292008000300004.

28. Angel, Y.; Esteban, W.; Bustos, R.; Pacheco, P.; Hurtado, E.; Bastías, E. Tomate "Poncho negro". Historia y rescate de un cultivo olvidado. IDESIA, 2016, 34(5), 65-69. DOI: 10.4067/S0718-34292016005000029. 